\title{
KOMPETENSI PROFESIONAL GURU UNTUK MENINGKATKAN MUTU PEMBELAJARAN DI SD 030425 SIMERPARA KABUPATEN PAKPAK BHARAT
}

\author{
Yuni Mariani Manik ${ }^{1}$, Jubelando O Tambunan², Darwin Bangun ${ }^{3}$ \\ Universitas Efarina Pematangsiantar \\ Yunimariani92@gmail.com
}

\begin{abstract}
Abstrak. Di dalam masyarakat, dari yang paling terbelakang sampai yang paling maju, guru memegang peranan penting hampir tanpa terkecuali, guru merupakan satu diantara pembentuk-pembentuk utama calon warga masyarakat. Sesuai Undang-Undang Republik Indonesia Nomor 14 Tahun 2005 tentang Guru dan Dosen Pasal 2 ayat (1) menegaskan bahwa guru mempunyai kedudukan sebagai tenaga profesional pada jenjang pendidikan dasar, pendidikan menengah, dan pendidikan anak usia dini pada jalur pendidikan formal yang diangkat sesuai dengan peraturan perundang-undangan. Berangkat dari paradigma tersebut, penelitian ini bertujuan untuk mengetahui kompetensi profesional guru untuk meningkat meningkatkan mutu pembelajaran di SD. Penelitian ini menggunakan pendekatan kualitatif dengan metode wawancara mendalam dan dokumentasi. Pemeriksaan keabsahan data dilakukan dengan memperpanjang waktu penelitian dan triangulasi. Hasil penelitian menunjukkan bahwa: (1) Profesional guru merupakan salah satu faktor yang sangat penting dalam meningkatkan mutu pendidikan (2) Mutu pembelajaran di diwujudkan dengan penerapan pembelajaran aktif, kreatif, dan menyenangkan serta melalui penelitian tindakan kelas. (3) Upaya Kepala Sekolah Dasar dalam meningkatkan professional guru di SD Negeri 030425 adalah dengan meningkatkan kompetensi guru melalui kursus dan diklat, pengadaan sumber dan media Pembelajaran, mengelola lingkungan belajar, penerapan e-learning, dan controling (4) Upaya guru dalam meningkatkan profesionalnya dengan mengikuti diklat dan Kelompok Kerja Guru, dan membuat penelitian tindakan kelas.
\end{abstract}

Kata Kunci: Kompetensi Profesional Guru; Mutu Pembelajaran

\section{PENDAHULUAN}

Kualitas manusia yang diinginkan oleh bangsa Indonesia pada masa yang akan datang adalah yang mampu menghadapi persaingan yang semakin ketat dengan bangsa lain di dunia. Kualitas manusia Indonesia tersebut dihasilkan melalui penyelenggaraan pendidikan yang bermutu. Oleh karena itu, guru mempunyai fungsi, peran, dan kedudukan yang sangat penting. Itulah sebabnya, guru harus senantiasa mengembangkan kemampuan dirinya. Guru perlu memiliki standar profesi dengan menguasai materi serta strategi pembelajaran dan dapat mendorong siswanya untuk belajar sungguh-sungguh.
Sesuai Undang-Undang Republik Indonesia Nomor 14 Tahun 2005 tentang Guru dan Dosen Pasal 2 ayat (1) menegaskan bahwa guru mempunyai kedudukan sebagai tenaga profesional pada jenjang pendidikan dasar, pendidikan menengah, dan pendidikan anak usia dini pada jalur pendidikan formal yang diangkat sesuai dengan peraturan perundangundangan. Pada Pasal 4 juga dijelaskan bahwa kedudukan guru sebagai tenaga professional sebagaimana dimaksud dalam Pasal 2 ayat (1) berfungsi untuk meningkatkan martabat dan peran guru sebagai agen pembelajaran berfungsi untuk meningkatkan mutu pendidikan nasional. 
Dengan demikian, tidak dapat dipungkiri bahwa guru harus memiliki pengetahuan yang luas, menguasai berbagai jenis bahan pembelajaran, menguasai teori dan praktik pendidikan, serta menguasai kurikulum dan metodologi pembelajaran. Kompetensi guru adalah salah satu faktor yang mempengaruhi tercapainya tujuan pembelajaran dan pendidikan di Sekolah Dasar, namun kompetensi guru tidak berdiri sendiri, tetapi dipengaruhi latar belakang pendidikan, pengalaman mengajar, dan lamanya mengajar. Kompetensi guru dapat dinilai penting sebagai alat seleksi dalam penerimaan calon guru, juga dapat dijadikan sebagai pedoman dalam rangka pembinaan dan pengembangan tenaga guru.Sealain itu, penting dalam hubungannya kegiatan belajar mengajar dan hasil belajar siswa. Dengan kompetensi profesional tersebut, dapat diduga berpengaruh pada proses pengelolaan pendidikan sehingga mampu menghasilkan pendidikan yang bermutu.

Demikian halnya yang berlangsung di SD Negeri 030425 Simerpara Pakpak Bharat, sarat dengan prestasi baik dari segi pendidiknya maupun siswanya. Beberapa gurunya pernah meraih predikat sebagai guru berprestasi dan sebagai guru teladan. Hal ini diraih tentunya karena adanya kompetensi yang dimiliki oleh guru-guru SD Negeri 030425 Simerpara Pakpak Bharat khususnya kompetensi profesional sehingga SD Negeri 030425 Simerpara Pakpak Bharat banyak meraih prestasi. Berdasarkan hal tersebut di atas, maka penelitian ini mengambil lokasi di SD Negeri 030425 Simerpara Pakpak Bharat.

\section{Rumusan Masalah}

Berdasarkan identifikasi tersebut, maka masalah-masalah dalam penelitian ini dapat dirumuskan sebagai berikut:

1. Bagaimana kompetensi profesional guruguru di SD Negeri 030425 Simerpara Pakpak Bharat?

2. Bagaimana mutu pembelajaran di SD Negeri 030425 Simerpara Pakpak Bharat?

3. Bagaimana upaya Kepala Sekolah dalam meningkatkan kompetensi profesional guru-guru di SD Negeri 030425 Simerpara Pakpak Bharat?

4. Bagaimana upaya guru meningkatkan mutu pembelajaran di SD Negeri 030425 Simerpara Pakpak Bharat.

Tujuan penelitian ini adalah untuk mendapatkan informasi yang komprehensif dan mendalam tentang kompetensi professional guru untuk meningkatkan mutu pembelajaran di SD Negeri 030425 Simerpara Pakpak Bharat. Secara rinci, penelitian ini bertujuan untuk:

1. Mengetahui strategi dan metode yang dipraktikkan guru dalam membelajarkan peserta didik untuk meningkatkan mutu pembelajaran di SD Negeri 030425 Simerpara Pakpak Bharat.

2. Mengetahui nilai-nilai dan sikap yang ditunjukkan guru dalam membelajarkan peserta didik untuk meningkatkan mutu pembelajaran di SD Negeri 030425 Simerpara Pakpak Bharat.

3. Mengetahui upaya-upaya yang dilakukan guru dalam mengembangkan kompetensi professional untuk meningkatkan pembelajaran di SD Negeri 030425 Simerpara Pakpak Bharat.

4. Mengetahui kendala-kendala yang dihadapi guru dalam mengembangkan kompetensi professional untuk meningkatkan pembelajaran di SD Negeri 030425 Simerpara Pakpak Bharat.

\section{Manfaat Penelitian}

Hasil penelitian ini diharapkan memberikan manfaat sebagai berikut:

1. Manfaat Praktis

a. Bagi peneliti, dapat menambah pengalaman dan keterampilan cara menumbuhkan dan menerapkan kompetensi profesional dalam pembelajaran.

b. Bagi Sekolah Dasar, dapat dijadikan acuan atau pedoman utuk memberikan rekomendasi kepada kepala Sekolah Dasar dan guru-guru yang lain dalam masalah kompetensi profesional.

c. Bagi Universitas, penelitian ini dapat menambah koleksi kajian tentang 
kompetensi profesional guru di Sekolah Dasar.

2. Manfaat Teoritis

a. Memberikan sumbangan bagi perkembangan ilmu pengetahuan khususnya masalah kompetensi profesional guru.

b. Dapat dijadikan sebagai bahan rujukan bagi peneliti selanjutnya pada kajian yang sama tetapi pada ruang lingkup yang lebih luas dan mendalam di bidang kompetensi guru.

\section{METODE PENELITIAN}

\section{Lokasi Penelitian}

Penelitian ini dilakukan di Sekolah Dasar Negeri No. 030425 Simerpara. Sekolah Dasar ini terletak di Desa Nambungobuluh, Kecamatan Pergetteng-getteng Sengkut Kabupaten Pak-pak Bharat.

\section{Subjek Penelitian.}

Subjek penelitian ini terdiri dari Kepala SD Negeri 030425 Simerpara Pakpak Bharat, Guru dan Pegawai SD Negeri 030425 Simerpara Pakpak Bharat.

Data yang diperoleh dari Kepala Sekolah SD Negeri 030425 Simerpara Pakpak Bharat adalah data tentang kebijakan dan usahausaha Kepala Sekolah Dasar sebagai upaya meningkatkan kompetensi profesional guru dalam proses pembelajaran.

Data yang diperoleh dari Guru- Guru SD Negeri 030425 Simerpara Pakpak Bharat adalah data tentang:

1. Strategi yang digunakan dalam proses pembelajaran.

2. Metode Pembelajaran

3. Nilai-nilai dan sikap yang ditonjolkan dalam pembelajaran.

4. Upaya-upaya yang dilakukan guru untuk meningkatkan kompetensi profesionalnya.

5. Kendala-kendala yang dihadapi dalam mengembangkan kompetensi profesionalnya.
030425 Simerpara Pakpak Bharat adalah data tentang data Sekolah Dasar yang meliputi data pendidik dan tenaga pendidikan, data siswa, data sarana dan prasarana, dan data lain yang relevan dengan masalah yang diteliti.

\section{Subjek Penelitian.}

Subjek penelitian ini terdiri dari Kepala SD Negeri 030425 Simerpara Pakpak Bharat, Guru dan Pegawai SD Negeri 030425 Simerpara Pakpak Bharat.

Data yang diperoleh dari Kepala Sekolah SD Negeri 030425 Simerpara Pakpak Bharat adalah data tentang kebijakan dan usahausaha Kepala Sekolah Dasar sebagai upaya meningkatkan kompetensi profesional guru dalam proses pembelajaran.

Data yang diperoleh dari Guru-Guru SD Negeri 030425 Simerpara Pakpak Bharat adalah data tentang:

1. Strategi yang digunakan dalam proses pembelajaran.

2. Metode Pembelajaran

3. Nilai-nilai dan sikap yang ditonjolkan dalam pembelajaran.

4. Upaya-upaya yang dilakukan guru untuk meningkatkan kompetensi profesionalnya.

5. Kendala-kendala yang dihadapi dalam mengembangkan kompetensi profesionalnya.

Data yang diperoleh dari Pegawai SD Negeri 030425 Simerpara Pakpak Bharat adalah data tentang data Sekolah Dasar yang meliputi data pendidik dan tenaga pendidikan, data siswa, data sarana dan prasarana, dan data lain yang relevan dengan masalah yang diteliti.

\section{Prosedur Pengumpulan Data}

1. Observasi

2. Wawancara Mendalam

3. Studi Dokumen
Analisis Data
1. Reduksi Data
2. Penyajian Data
3. Penarikan Kesimpulan 


\section{HASIL DAN PEMBAHASAN}

Kompetensi guru adalah salah satu faktor yang mempengaruhi tercapainya tujuan pembelajaran dan pendidikan diSekolah Dasar, namun kompetensi guru tidak berdiri sendiri, tetapi dipengaruhi latar belakang pendidikan, pengalaman mengajar, dan lamanya mengajar. Kompetensi guru dapat dinilai penting sebagai alat seleksi dalam penerimaan calon guru, juga dapat dijadikan sebagai pedoman dalam rangka pembinaan dan pengembangan tenaga guru. Selain itu, penting dalam hubungannya kegiatan belajar mengajar dan hasil belajar siswa. Dengan kompetensi profesional tersebut, dapat diduga berpengaruh pada proses pengelolaan pendidikan sehingga mampu melahirkan keluaran pendidikan yang bermutu. Keluaran pendidikan yang bermutu dapat dilihat dari hasil langsung pendidikan yang berupa nilai yang dicapai siswa dan dapat juga dilihat dari dampak pengiring, yaitu peserta didik setelah di masyarakat.

Guru yang memiliki kompetensi profesional adalah guru yang memiliki pengetahuan yang luas dari subject matter (bidang studi) yang akan diajarkan serta penguasaan metodologi dalam arti memiliki konsep teoritis mampu memilih metode dalam proses belajar mengajar.

Berdasarkan informasi yang dihimpun dari Ibu Kepala Sekolah Dasar 030425 Simerpara Pakpak Bharat, menunjukkan bahwa guruguru Sekolah Dasar 030425 Simerpara Pakpak Bharat adalah guru-guru yang professional, hal ini dibuktikan dengan:
a. $100 \%$ guru-guru SD Negeri 030425 Simerpara Pakpak Bharat adalah sarjana.
b. Bertanggung jawab terhadap tugasnya.
c. Berwawasan luas.
d. Pengalaman mengajar rata-rata di atas 5 tahun.
e. Menggunakan strategi pembelajaran secara variatif.
f. Menggunakan bahan bantu mengajar dengan epektif.
g. Setiap tahun mempersiapkan prangkat pembelajaran secara lengkap.

h. Berprestasi dalam bidangnya masingmasing.

Strategi Pembelajaran di SD Negeri 030425 Simerpara Pakpak Bharat. Berdasarkan hasil observasi pada hari rabu, tanggal 6 Februari 2019 dikelas VI, ada dua strategi pembelajaran yang menonjol di Sekolah Dasar Negeri 030425 Simerpara Pakpak Bharat yakni strategi pembelajaran Kooperatif dan strategi pembelajaran PAIKEM (Pembelajaran Aktif, Inovatif, Kreatif, Efektif, dan Menyenangkan).

Penerapan paikem dilatarbelakangi oleh kenyataan bahwa selama ini pembelajaran berlangsung cenderung membuat siswa bosan dan malas. Dengan penerapan pembelajaran paikem cendrung siswa secara aktif bersamasama dengan guru terlibat dalam kegiatan pembelajaran.

Metode Pembelajaran di Sekolah Dasar Negeri 030425 Simerpara. Tahapan pelaksanaan pembelajaran di kelas dapat diuraikan sebagai berikut:

1. Penyampaian tujuan dan memotivasi siswa, pada tahap ini guru menyampaikan semua tujuan pelajaran yang ingin dicapai pada pelajaran tersebut dan memotivasi siswa belajar.

2. Menyajikan informasi, disini guru menyajikan informasi kepada siswa dengan jalan demonstrasi atau lewat bahan bacaan.

3. Mengorganisasikan siswa ke dalam kelompok kooperatif, Guru menjelaskan kepada siswa bagaimana caranya membentuk kelompok belajar dan membantu setiap kelompok agar melakukan transisi secara efisien.

4. Membimbing kelompok bekerja dan belajar, Guru membimbing kelompokkelompok belajar pada saat mereka mengerjakan tugas- tugas mereka.

5. Evaluasi, Guru mengevaluasi hasil belajar tentang materi yang telah dipelajari atau masing-masing kelompok mempersentasikan hasil kerjanya.

6. Memberikan Penghargaan, Guru mencari cara-cara untuk menghargai baik upaya maupun hasil belajar individu 
maupun kelompok.

Secara umum, penanaman nilai- nilai dan sikap yang ditunjukkan guru saat pembelajaran di SD Negeri 030425 Simerpara Pakpak Bharat sebagai berikut:

a. Tanggung Jawab; Seluruh tugas pendidikan dan bantuan kepada anak didik memerlukan tanggungjawab yang besar. Pendidikan yang menyangkut perkembangan anak didik tidak dapat dilakukan seenaknya, tetapi perlu direncanakan, perlu dikembangkan dan perlu dilakukan dengan tanggungjawab.

b. Disiplin; Kedisiplinan menjadi unsur penting bagi seorang guru. Kedisiplinan ini memang menjadi kelemahan bangsa Indonesia, yang perlu diberantas sejak bangku sekolah dasar. Untuk itu guru sendiri harus hidup dalam kedisiplinan sehingga anak didik dapat meneladannya. Di lapangan terlihat bahwa guru SD Negeri 030425 Simerpara Pakpak Bharat sangat disiplin, misalnya: hadir tepat waktu, tidak seenaknya bolos, mengoreksi pekerjaan siswa sehingga siswa mendapat masukan dari pekerjaan mereka.

c. Kasih Sayang; Tidak bersikap diskriminatif terhadap peserta didik, teman sejawat, orang tua peserta didik dan lingkungan sekolah karena perbedaan agama, suku, jenis kelamin, latar belakang keluarga, dan status sosial-ekonomi, disini guru memperlakukan setiap murid sama dan tidak pilih kasih.

d. Kejujuran; Secara sederhana kejujuran yang ditunjukkan oleh guru misalnya mencatat waktu kehadiran sesuai dengan kehadirannya sewaktu mengisi absensi kehadiran.

e. Keteladanan; Keteladanan seorang guru dimaksudkan bertindak sesuai dengan norma religius (iman dan taqwa, jujur, ikhlas, suka menolong), dan memiliki perilaku yang diteladani peserta didik. Misalnya: Disiplin waktu, berbusana sopan, sabar, tidak mudah marah dan saling mengingatkan satu sama lain.

Ada beberapa alternatif pengembangan profesi yang dapat dilakukan guru, yaitu:

a. Program-program penataran atau kursuskursus, kegiatan-kegiatan ilmiah, dan Workshop. Untuk hal tersebut kepala sekolah sangat mendukung bagi peningkatan kompetensi guru melalui kegiatan diklat maupun. Untuk meningkatkan profesionalisme guru, pihak sekolah mewajibkan para guru mengikuti Kelompok Kerja Guru (KKG) dan Musyawarah Guru Mata Pelajaran (MGMP) yang dilaksanakan satu bulan sekali. Kepala sekolah juga sering mengutus para guru untuk mengikuti diklat maupun workshop yang dilaksanakan baik oleh Dinas Pendidikan maupun Badan Diklat Kementerian Agama.

b. Sikap pro-aktif guru dalam mengembangkan wawasan

kependidikan sesuai dengan bidangnya, ini dapat dilakukan dengan keikutsertaan guru dalam pelatihan-pelatihan dengan inisiatif sendiri dan biaya sendiri.

c. Penelitian Tindakan Kelas (PTK), di samping kegiatan diklat maupun workshop, upaya meningkatkan mutu pembelajaran menurut Ibu Fauziah, S.Pd I, dilakukan dengan penelitian tindakan kelas (PTK).

Adapun hasil yang diperoleh dari penelitian ini tentang upaya kepala Sekolah Dasar dalam meningkatkan kompetensi profesional guru sebagaimana disampaikan oleh Bapak Kepala Sekolah sebagai berikut:

a. Pembinaan Kompetensi Guru; Kepala Sekolah berupaya dengan memotivasi guru untuk terus berkembang, dalam arti mengikuti perubahan dan perkembangan zaman sehingga tidak ketinggalan zaman. Misalnya, saat ini kita berada di era teknologi informasi dan komputerisasi, maka mau tidak mau seorang guru harus mampu mengoperasionalkan komputer, memanfaatkan sarana internet dan media lain yang dapat membantu tugasnya sebagai guru yang professional. Untuk meningkatkan kualitas guru tersebut, pihak Sekolah 
telah memfasilitasi para guru untuk: kursus komputer di Sekolah, Mengikutkan guru dalam berbagai pelatihan guna mengembangkan potensi tenaga pendidik, maupun kegiatan mandiri, membentuk forum diskusi guru (FDG) atau lebih dikenal di masyarakat luas sebagai Kelompok Kerja Guru (KKG). Dalam FDG diharapkan ada sharing konwledge, peer teaching dan berbagi pengalaman antar guru serta memecahkan masalah yang dihadapi Guru di kelas-kelas mereka.

b. Penyediaan dan pengembangan Sumber dan Media Belajar. Kepala Sekolah menyadari bahwa pembelajaran bermakna akan berlangsung jika siswa terlibat secara aktif dalam menemukan konsep melalui pengalaman langsung dengan media dan sumber belajar. Untuk itulah maka, SD Negeri 030425 Simerpara Pakpak Bharat berkomitmen secara penuh dan bertahap memenuhi kebutuhan sumber dan media belajar.

c. Pengelolaan lingkungan belajar; Salah satu prinsip dari teori behaviourisme ialah lingkungan berpengaruh dalam perubahan perilaku. Paling sederhana dapat dilihat bahwa siswa tidak akan memiliki motivasi belajar yang tinggi jika lingkungan belajar tidak tertata dengan baik. Untuk itulah maka SD Negeri 030425 Simerpara Pakpak Bharat bertahap melakukan pembenahan lingkungan belajar baik di dalam maupun diluar kelas agar terbentuk lingkungan yang ASRI (aman, sehat, resik dan indah). Kelaskelas diharapkan terkelola dengan baik dengan lebih banyak menampilkan informasi yang bersifat mendidik dan memberikan motivasi belajar. Dalam konteks ini maka semua siswa, guru dan karyawan diharapkan senantiasa menjaga dan mewujudkan lingkungan belajar yang bersih dan kondusif.

d. Pengontrolan mutu proses pembelajaran. Pelaksanaan pembelajaran di kelas merupakan aktivitas yang menjadi sentral pendidikan di Sekolah Dasar. Menyadari hal ini maka pengontrolan mutu pembelajaran menjadi hal yang sangat penting untuk dilaksanakan. Dalam kaitan dengan hal ini maka, Kepala Sekolah memberikan kebijakan agar semua guru pernah mengalami supervisi terjadwal maupun supervisi tidak terjadwal yang dilakukan oleh Kepala Sekolah, wakil Kepala Sekolah maupun Bagian Akademik. Supervisi dilakukan bukan semata terhadap pelaksanaannya, namun dari perencanaan, pelaksanaan hingga evaluasi tidak luput dari supervisi. Dengan terselenggaranya supervisi yang baik dan optimal maka diharapkan terjadi proses peningkatan mutu pembelajaran melalui pendampingan dan diperdalam pada Forum Diskusi Guru atau Kelompok Kerja Guru.

e. Pembinaan Siswa. Ujung dari proses pembelajaran ialah terbentuknya pengetahun, sikap dan perilaku positif dalam diri siswa. Oleh karena itu faktor siswa dalam penataan dan peningkatan mutu pembelajaran tidak dapat diabaikan. Penanaman sikap disiplin belajar, tertib dalam pelaksanaan, tuntas dalam pekerjaan dan beramal baik dalam keseharian merupakan halhal positif dalam pembelajaran di kelas. Terkait intervensi aspek internal siswa, Sekolah melakukan kegiatan pembinaan rutin, baik yang dilaksanakan setiap pekan melalui bimbingan pada upacara bendera setiap hari senin, maupun setiap hari melalui kegiatan pembelajaran di kelas oleh guru mata pelajaran ataupun guru kelasnya masing- masing.

\section{Hasil}

Secara umum guru-guru SD Negeri 030425 Simerpara Pakpak Bharat dinilai profesional, sebagaimana pengakuan Bapak Kepala Sekolah Dasar bahwa setiap guru mampu menguasai kelas, melaksanakan pembelajaran dengan epektif dan mampu menggunakan metode dan strategi secara tepat. Hal ini dibuktikan dengan prestasi 
yang diraih oleh beberapa guru kami, baik dalam bidang pembuatan alat peraga, penelitian tindakan kelas maupun pemilihan guru berprestasi. Hal tersebut menunjukkan bahwa guru SD Negeri 030425 Simerpara Pakpak Bharat adalah guru yang profesional.

Mutu pembelajaran di Sekolah Dasar Berdasarkan hasil observasi, umumnya guru-guru di SD Negeri 030425 Simerpara Pakpak Bharat menerapkan model pembelajaran koperatif dengan langkahlangkah:

a. Penyampaian tujuan dan memotivasi siswa, pada tahap ini guru menyampaikan semua tujuan pelajaran yang ingin dicapai pada pelajaran tersebut dan memotivasi siswa belajar.

b. Menyajikan informasi, disini guru menyajikan informasi kepada siswa dengan jalan demonstrasi atau lewat bahan bacaan.

c. Mengorganisasikan siswa ke dalam kelompok kooperatif, Guru menjelaskan kepada siswa bagaimana caranya membentuk kelompok belajar dan membantu setiap kelompok agar melakukan transisi secara efisien.

d. Membimbing kelompok bekerja dan belajar, Guru membimbing kelompokkelompok belajar pada saat mereka mengerjakan tugas- tugas mereka.

e. Evaluasi, Guru mengevaluasi hasil belajar tentang materi yang telah dipelajari atau masing-masing kelompok mempersentasikan hasil kerjanya.

f. Memberikan Penghargaan, Guru mencari cara-cara untuk menghargai baik upaya maupun hasil belajar individu maupun kelompok.

Berdasarkan hasil observasi, metode-metode yang sering digunakan dalam proses pembelajaran di SD Negeri 030425 Simerpara Pakpak Bharat yakni: ceramah, tanya jawab, diskusi, pemberian tugas dan resitasi, serta Metode latihan.

Mencermati upaya reformasi pembelajaran yang sedang dikembangkan di Indonesia, guru saat ini banyak ditawari aneka pilihan model pembelajaran sehingga guru diharapkan secara kreatif mencoba dan mengembangkan model pembelajaran tersendiri yang secara khas sesuai dengan kondisi nyata ditempat kerjanya sehingga akan muncul model pembelajaran khas versi guru yang bersangkutan yang tentu semakin memperkaya khazanah model pembelajaran yang telah ada.

Berdasarkan hasil observasi dan penelitian menunjukkan bahwa penanaman nilai-nilai dan sikap yang ditunjukkan guru saat pembelajaran di SD Negeri 030425 Simerpara Pakpak Bharat sebagai berikut:

1. Tanggung Jawab; Dari pengalaman lapangan Menggambarkan bahwa guruguru SD Negeri 030425 Simerpara Pakpak Bharat sangat bertanggung jawab terhadap tugas pokok dan fungsinya masing-masing, misalnya: tidak pernah meninggalkan kelas saat proses pembelajaran berlangsung, kecuali ada masalah yang penting dan mendesak, guru mempersiapkan pelajaran dengan baik, guru memberikan bimbingan dan mengarahkan anak didik dengan baik.

2. Disiplin; Di lapangan terlihat bahwa guru SD 030425 Simerpara sangat disiplin, misalnya: hadir tepat waktu, tidak seenaknya bolos, mengoreksi pekerjaan siswa sehingga siswa mendapat masukan dari pekerjaan mereka.

3. Kasih Sayang; Tidak bersikap diskriminatif terhadap peserta didik, teman sejawat, orang tua peserta didik dan lingkungan sekolah karena perbedaan agama, suku, jenis kelamin, latar belakang keluarga, dan status sosial-ekonomi, disini guru memperlakukan setiap murid sama dan tidak pilih kasih.

4. Kejujuran; Secara sederhana kejujuran yang ditunjukkan oleh guru misalnya mencatat waktu kehadiran sesuai dengan kehadirannya sewaktu mengisi absensi kehadiran.

5. Keteladanan; Keteladanan seorang guru 
dimaksudkan bertindak sesuai dengan norma religius (iman dan taqwa, jujur, ikhlas, suka menolong), dan memiliki perilaku yang diteladani peserta didik. Misalnya: Disiplin waktu, berbusana sopan, sabar, tidak mudah marah dan saling mengingatkan satu sama lain.

Hasil penelitian menunjukan bahwa upaya guru dalam meningkatkan profesionalismenya adalah dengan mengikuti kegiatan Musyawarah Guru Mata Pelajaran (MGMP), penataran, Workshop dan pelatihan-pelatihan.

Berdasarkan hasil penelitian, upaya kepala Sekolah Dasar dalam meningkatkan kompetensi profesional guru dilakukan melalui:
a. Pembinaan Kompetensi Guru,
b. Penyediaan dan pengembangan Sumber dan Media Belajar,
c. Pengelolaan lingkungan belajar,
d. Pembangunan e-learning, dan
e. Pengontrolan mutu proses pembelajaran.

\section{SIMPULAN DAN SARAN}

\section{Simpulan}

Dari hasil penelitian yang dilakukan, dapat diambil kesimpulan bahwasanya pengurusan dan mengantar surat penelitian sudah dilaksanakan oleh peneliti. Pengambilan data melalui wawancara dan studi dokumen yang dilakukan oleh ketua dan anggota peneliti sudah dilaksanakan kemudian dikaji. Studi dokumen dalam penelitian ini dilakukan dengan mengkaji dokumen dokumen yang berkaitan dengan kompetensi professional guru di SD Negeri 030425 Simerpara Pakpak Bharat antara lain: kurikulum dan silabus, rencana pelaksanaan pembelajaran (RPP), dan daftar nilai.

Data ini dipergunakan untuk menambah data yang ada yang diperoleh melalui observasi dan wawancara yang kesemuanya untuk memperoleh pengertian yang mendalam. Setelah hasil dikaji diketahui kompetensi professional guru yang dapat meningkatkan mutu pembelajaran di SD Negeri 030425 Simerpara. Kompetensi professional guru SD
Negeri 030425 Simerpara Pakpak Bharat untuk meningkatkan mutu pembelajaran dapat disimpulkan sebagai berikut:

1. Kompetensi Guru Sekolah Dasar Ibtidaiyah Negeri Sei Agul Medan relatif baik, dimana semua guru berpredikat sarjana, memiliki prangkat pembelajaran, menerapkan pembelajaran dengan model pembelajaran kooperatif, Sudah tersertifikasi, dan ada yang berprestasi pada tingkat nasional. Kompetensi guru yang baik sangat berpengaruh kepada kualitas pembelajaran dan mutu pendidikan, demikian yang terjadi di SD Negeri 030425 Simerpara Pakpak Bharat sehingga banyak prestasi yang diraih.

2. Strategi dan Metode yang diwujudkan dengan penerapan pembelajaran Kooperatif dan pembelajaran aktif, inovatif, kreatif, epektif, dan menyenangkan serta melalui penelitian tindakan kelas.

3. Nilai-nilai yang ditunjukkan guru dalam proses pembelajaran diawali dengan internalisasi nilai-nilai terhadap guru secara pribadi agar menjadi guru yang berkepribadian baik sekaligus di realisasikan kepada para siswa melalui keteladanan guna terwujud siswa berkepribadian baik pula.

4. Upaya-upaya yang dilakukan guru dalam mengembangkan kompetensi professional dengan mengikuti diklat, penataran, workshop, dan Kelompok Kerja Guru, serta membuat penelitian tindakan kelas.

\section{Saran}

Berkaitan dengan usaha Kepala Sekolah dalam meningkatkan profesionalisme guru, yang perlu dilakukan adalah:

a. Mengikutsertakan guru/staf pada pelatihan yang sesuai. Jika perlu sekolah mengadakan pelatihan ditempat (in house training), dengan mengundang pelatih dari luar. Guru/staf yang selesai mengikuti pelatihan harus menularkan pengetahuannya kepada guru/staf yang lain.

b. Sekolah perlu menyediakan buku atau 
referensi yang memadai bagi guru/staf.

c. Mendorong dan memfasilitasi guru/staf untuk melakukan tutorial sebaya, misalnya melalui kegiatan MGMP untuk guru mata pelajaran dan MGBK untuk guru bimbingan konseling. Kepala sekolah juga perlu mendorong pertemuan berkala antar guru mata pelajaran sejenis di sekolah.

\section{DAFTAR RUJUKAN}

Abdul Majid, Perencanaan Pembelajaran: Mengembangkan Standar Kompetensi Guru (Bandung: PT Remaja Rosdakarya, 2005), h. 6.

Abdurrahman An Nahlawi, Pendidikan Islam di Rumah, Sekolah, dan Masyarakat; Penerjemah: Drs. Shihabuddin (Jakarta: Gema Insani Press, 1995), h. 170-176.

Abuddin Nata, Sejarah Pendidikan Islam Pada Periode Klasik dan Pertengahan (Jakarta: PT. Raja Grafindo Persada, 2004), h. 50.

Anna Poedjiadi, Sains Teknologi Masyarakat : Model Pembelajaran Kontekstual Bermuatan Nilai (Bandung: PT Remaja Rosda Karya dan Program Pascasarjana Universitas Pendidikan Indonesia, 2005), h. 97-98.

Anwar, Moch. Idochi, Administrasi Pendidikan dan Manajemen Biaya Pendidikan., Bandung: Alfabeta, 2004.

Arikunto, Suharsimi, Manajemen Pengajaran Secara Manusia. Jakarta: Rineka Cipta, 1993.

Baharuddin Harahap, Supervisi Pendidikan yang Dilaksanakan oleh Guru, Kepala Sekolah, Penilik dan Pengawas Sekolah (Jakarta: Damai Jaya, 1983), h. 32

Danim, Sudarwan, Visi Baru Manajemen
Sekolah Dasar, Jakarta : Bumi Aksara, 2007

Dede Rosyada, Paradigma Pendidikan Demokratis: Sebuah Model Pelibatan Masyarakat dalam menyelenggaraan Pendidikan, (Jakarta : Kencana, 2004), h. 112.

Departemen Agama RI, Kumpulan UndangUndang dan Peraturan Pemerintah RI tentang Pendidikan (Jakarta: Dirjen Pendidikan Islam Departemen Agama RI, 2007), h. 74.

Departemen Pendidikan Nasional, Undangundang Sistem Pendidikan Nasional (Jakarta: Grafindo, 2004), h. 7.

Dirjen Pendidikan Islam, Kumpulan UndangUndang dan Peraturan Pemerintah RI tentang Pendidikan, Jakarta, DEPAG RI, 2007.

Djam'an Satori dan Aan Komariah, Metodologi Penelitian Kualitaif (Bandung: ALFABETA, 2009), h. 23.

Djamarah, Syaiful Bahri, Guru dan Anak Didik Dalam Interaksi Edukatif: Suatu pendekatan teoritis psokilogis, Jakarta: Rineka Cipta, 2010.

Edward Sallis, Total Quality Management In Education; Ahmad Ali Riyadi, Manajemen Mutu Terpadu dalam Pendidikan (Jogjakarta : IRCiSoD, 2006), h. 33.

Eti Rochaety, et. al., Sistem Informamsi Manajemen Pendidikan (Jakarta : bumi Aksara, 2005), h. 8.

E. Mulyasa, Kurikulum Berbasis Konsep, Karakteristik dan implementasi (Bandung: PT Remaja Rosdakarya, 2003) $h 38$

E. Mulyasa, Implementasi Kurikulum 2004 Panduan Pembelajaran KBK (Bandung: PT.Remaja Rosdakarya, 
2004), h.169

Hanun Asrohah, Sejarah Pendidikan Islam (Jakarta: Kalimah, 1999), h.155.

Indra Djati Sidi, Menuju Masyarakat Belajar (Jakarta : Logos, 2003), h. 73.

Kusrini, Siti, et. al, Keterampilan Dasar Mengajar (PPL 1), Berorientasi Pada Kurikulum Berbasis Kompetensi (Malang: Fakultas Tarbiyah UIN Malang, 2005.

Lalu Sumayang, Manajemen produksi dan Operasi (Jakarta : Salemba Empat, 2003), h.322

Muhammad Surya, Psikologi Pembelajaran dan Pengajaran (Bandung: Yayasan Bhakti Winaya, 2003), 138

Muhibbin Syah, Psikologi Pendidikan dengan Pendekatan Baru (Bandung: PT Remaja Rosdakarya, 2000), h. 229.

Moh. Uzer Usman, Menjadi Guru Profesional (Bandung: PT Remaja Rosdakarya, 1994), h1

Moch. Idochi Anwar, Administrasi Pendidikan dan Manajemen Biaya Pendidikan. (Bandung: Alfabeta, 2004), h. 63.

Moleong, Lexy J. Moleong, Metodologi Penelitian Kualitatif, Cet.I, Bandung: Remaja Rosdakarya, 2000.

Nur Ali, Pengembangan Buku Ajar Pendidikan Agama Islam (STAIN Malang, 2003), h.32 
